Isidora Beraha ${ }^{1}$

Sonja Đuričin ${ }^{2}$

Institute of Economic Sciences, Belgrade
SCIENTIFIC REVIEW ARTICLE

doi:10.5937/ekonomika2001093B

Received: October, 28. 2019.

Accepted: January, 24.2020.

\title{
SURVEY ON WOMEN'S INNOVATIVE ENTREPRENEURSHIP IN SERBIA ${ }^{3}$
}

\begin{abstract}
The main objective of the research is to analyse and assess the innovative potential of women entrepreneurs in Serbia. A field survey was conducted in order to realize the research objective. The questionnaire was designed to gather perceptions of women entrepreneurs on the following five factors: motivation of women to be entrepreneurs, conditions and opportunities for conducting innovative activity in Serbia, investments in innovative activity, level of cooperation with relevant institutions in national innovation ecosystem, and familiarity with the role and measures of institutions supporting innovative activities in Serbia. Considering an even geographical coverage the sample included 30 women entrepreneurs in 6 areas. Based on the survey results, the innovative potential of women entrepreneurs in Serbia can be assessed as relevant but underdeveloped. In order to develop their innovative potential, improve innovative performances and increase the level of participation in innovative activities, a set of recommendations for policy makers is suggested in the paper.
\end{abstract}

Key words: women's entrepreneurship, innovative potential, field survey, Serbia.

JEL classification: L26, O30, M21

\section{ИСТРАЖИВАЊЕ ПОТЕНЦИЈАЛА ЗА РАЗВОЈ ИНОВАТИВНОГ ЖЕНСКОГ ПРЕДУЗЕТНИШТВА У СРБИЈИ}

\section{Апстракт}

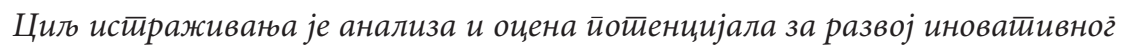

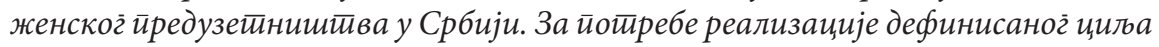
истираживана, сироведено је иеренско истираживане на узорку од 30 жена ирредузеитнкка у 6 геогррабски равномерно расиооређених йодручја. Уйийник је кониииичран на начин да обезбеди ирикуйлане инбормација о иериеиичијама

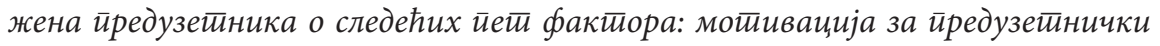

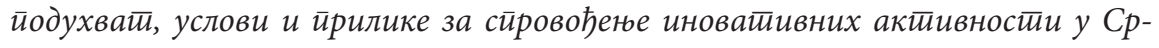

\footnotetext{
${ }^{1}$ isidora.beraha@ien.bg.ac.rs, ORCID number: 0000-0002-0819-4909

${ }^{2}$ sonja.djuricin@ien.bg.ac.rs, ORCID number: 0000-0002-8181-7332

${ }^{3}$ This paper is a result of research financed by the Ministry of Education, Science and Technological Development of the Republic of Serbia. Also, this research is supported by PERFORM project of Swiss Agency for Development and Cooperation (SDC), implemented by HELVETAS Swiss Intercooperation and University of Fribourg
} 
бији, инвестиииије у иновативне акииивностии, ниво сарадюе са релеванитним

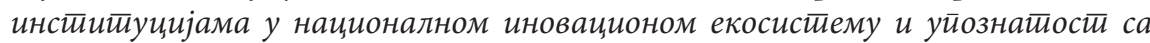

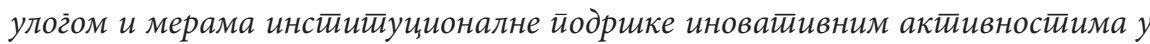
Србији. На основу резулитайа истираживаға, иотеиенијал за развој иноваииивног женског̄ ирредузетинишитва у Србији је оценен као релеванйан али недо-

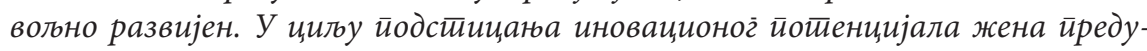

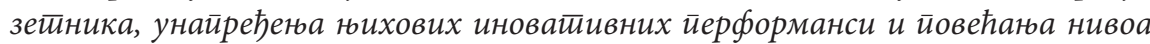

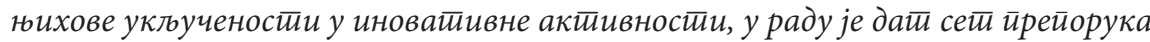
за креайоре економске йолииике.

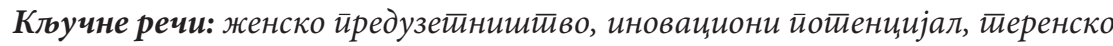
истираживане, Србија.

\section{Introduction}

Economic development of nations is driven by strong private sectors characterized by enterprises that invest, increase productivity and create new jobs. Along with abandoning the dominant reliance on big businesses and mass production, the importance of the role of entrepreneurship is constantly increasing. The importance of entrepreneurship is particularly relevant in modern, dynamic business environment since smaller scale enterprises and entrepreneurs are flexible, innovative and adaptable to rapid changes in the market.

Both entrepreneurship and innovation have positive effects on economic growth and development (Đuričin and Beraha, 2018). Innovations are considered as a key factor for achieving smart, sustainable and inclusive growth which is defined by the EU strategic documents as a priority goal. Innovation leads to new products and services or new ways of production and delivery and those are main assumptions of competitiveness of national economies, environment protection, health and general human well-being. In order to protect a competitive position in the future, it is necessary to embrace risk taking innovations, disturbing current business routines (Erić Nielsen, Stojanović-Aleksić \& Zlatanović, 2019).

At the same time, entrepreneurship is associated with the generation of new ideas. Entrepreneurship is by its definition related to innovative activity. The entrepreneurs tend to predict and respond to changes within markets and bears the uncertainty of market dynamics (Knight, 1942). The entrepreneur is the innovator who introduces change within markets through the introduction of a new product or quality or new method of production, opening of a new market, introducing new source of supply of new materials or parts, and new organization of any industry (Schumpeter, 1934). No matter if it occurs in an existing business, public service institution or a new business venture started by an individual, innovation is the specific function of entrepreneurship (Drucker, 2002).

Relationship between entrepreneurship, innovation and economic development along with the growing importance and actuality of innovative activities, have determined the subject of the research presented in this paper. Since there is an extensive literature on the general role and importance of entrepreneurship, it will remain outside the coverage of this paper. Because there is much less research on different aspects of 
women's entrepreneurship, the subject of the research is narrowly focused on women entrepreneurs, and more precisely on innovative women entrepreneurs.

Along with the sector of small and medium-sized enterprises, women's entrepreneurship is important for economic development for it contributes to reduction of unemployment, establishment of businesses in new spheres, implementation of new technologies, development of entrepreneurial sector, as well as to real GDP growth, regional and rural development (Jovanović and Lazić, 2018). Women's entrepreneurship is an important issue in terms of gender equality and women empowerment, but also for the promotion of sustainable development and economic growth through the creation of high growth, innovative enterprises (Radović-Marković et al., 2019; UNCTAD, 2013).

With an aim to fill the existing gap in research and literature on innovative activity of women entrepreneurs, this paper contributes an empirical study on several aspects of innovative women's entrepreneurship in Serbia and suggests a set of recommendations for policy makers based on the field survey results. The main objective of the research is to analyse and assess the innovative potential of women entrepreneurs in Serbia. In order to evaluate the innovative potential of women entrepreneurs, a field survey was conducted. The questionnaire was designed to gather information and perceptions of women entrepreneurs on the following five factors relevant for the assessment of innovative potential: motivation of women to be entrepreneurs, conditions and opportunities for conducting innovative activity in Serbia, investments in innovative activity, level of cooperation with relevant institutions in innovation ecosystem, and familiarity with the role and measures of institutions supporting innovative activities in Serbia.

\section{Literature review}

In the broad context of entrepreneurship, the very special nature and characteristics of women entrepreneurs imply a separate approach to the consideration of this phenomenon. Unlike male's entrepreneurship, women's entrepreneurship is characterized by strong social dimension. Personal characteristics of women entrepreneurs and their motives for running business differ from those of men entrepreneurs. While independence and the need for self-achievement are common motives for both male and female entrepreneurs according to Hisrich (1990), women entrepreneurs are strongly encouraged by the flexibility of working hours (Orhan and Scott, 2001) that provides them with enough time for home duties, socializing, family issues, relaxing, etc. Many women find it difficult to reconcile family responsibilities with inflexible employment in the formal sector (Baughn, Chua \& Neupert, 2006). Working at home enables women to avoid long business meeting and boss' critics and allows more freedom and different opportunities for quality use of time, however it often leads to traps of lacking organizational capabilities, having hard time with organizing commitments and time, and sometimes even losing their identity (Radović-Marković, 2018). Brush (2009) suggests that there are three main differences between men and women entrepreneurs: representation in the business sector, entrepreneurial process, and access to resources -especially growth capital. Avolio and Radović-Marković (2013) suggest that there are two categories of factors that explain women involvement in entrepreneurial activity, whereby the first one refers to circumstances such as personal, economic, work or family related 
situations or events, and the second one refers to motives and is related to achievement, autonomy, power and affiliation..

Zapalska (1997) found significant differences between men and women regarding the objectives for their ventures and their perceptions on critical success factors. While $99 \%$ of male entrepreneurs stated that their main goal is to acquire the short-term profitability, it was states as a goal by only $59 \%$ of female entrepreneurs. On the other hand, long-term capital accumulation and investment is a priority for $89 \%$ of women and only $12 \%$ of men entrepreneurs. Also, the most important factors as perceived by women refer to innovation/creation of something new, professional attitude, and establishment of business contacts, while these factors are not perceived as important by men entrepreneurs (Zapalska, 1997 in Bliss \& Garratt, 2001).

Consideration of the main reasons and motivation of women to be entrepreneurs is an important issue particularly when attempting to assess the potential for innovative activities since entrepreneurship is not related to an enterprise's size and age but to a certain kind of activity (Drucker, 2002).

In the last decade, many changes in regard of women entrepreneurship have occurred in developing countries, whereby the most significant one refers to the increasing share of women entrepreneurs in the total number of entrepreneurs in both national economies and in the global economy (Jovanović and Lazić, 2018). However, despite being one of the fastest rising populations of entrepreneurs and making significant contribution to innovation, job and wealth creation, women are vastly understudied (De Bruin, Brush \& Welter, 2006). Also, when being subject of analysis, women entrepreneurs are often considered as a homogenous category. For example, there are significant differences in terms of available resources between necessity-driven and opportunity-driven women entrepreneurs (Minniti, Arenius, \& Langowitz, 2005).

Women entrepreneurs contribute to economic development not only through employment and wealth creation, but also by improving the diversity of entrepreneurial activity and the overall quality of entrepreneurship (Verheul \& Thurik 2001, Verheul, Van Stel \& Thurik, 2006, Verheul \& Van Stel, 2007 in Nissan, Carrasco \& Castano, 2012). In their empirical study on women entrepreneurship, innovation and internalization Nissan, Carrasco \& Castano (2012) found that the contribution of male and female entrepreneurship to economic growth can be compared but since the rates of male entrepreneurship are higher, their contribution is proportionally higher, as well as that the lower rates of female entrepreneurship are due to many factors such as different preferences, discrimination, and risk aversion. Also, they concluded that there is a positive relationship between innovation and economic growth for both entrepreneur groups, without significant differences among them. According to Stošić et al. (2019) there is a positive relationship between innovation and entrepreneurship when both men and women begin their businesses to profit from a market opportunity, and there is no significant gender difference except for the higher rates of male entrepreneurship. However, when the entrepreneurial activity is driven by necessity, this relationship is negative which means that the degree of innovation is lower.

The nature, extent and the potential economic contribution of women's entrepreneurship is influenced by the institutional and legal contexts (Welter, 2004). Baughn, Chua \& Neupert (2006) found that specific normative support for women entrepreneurs is highly associated with general positive regard for entrepreneurship and 
level of gender equality in a society. Some researchers argue that there is a lack of formal support for women entrepreneurs (Bliss \& Garratt, 2001). According to Warnecke (2013) both formal and informal institutions play an important role, and while formal institutions include laws and regulations, informal institutions are associated with societal norms and attitudes which are much harder to change, but they significantly limit opportunities for women.

Bliss \& Garratt (2001) argue that institutional support to women entrepreneurs in transitioning economies should focus on the following areas: (i) easy access to information about starting and running a small business; (ii) training programs in the areas of business plan preparation, marketing strategies, human resource management, and financial management; (iii) providing access to mentoring relationships; (iv) modifying societal and cultural stereotypes that penalize women in business; (v) lobbying government agencies to reduce burdensome tax policies and the bureaucratic red tape that hinder entrepreneurial activity. Brindley (2005) points out that it is necessary to understand the gender aspects of risk for policy measures to be efficient and help women overcome barriers and achieve their entrepreneurial potential.

Estrin \& Mickiewicz (2011) analysed how institutions affect men and women decisions to start new business in the period 2001-2006, and they found that women are less likely to undertake entrepreneurial activity in countries where the state sector is larger, but the rule of law is not gender sensitive.

A survey conducted by the UNCTAD in 2012 provided insights on drivers and obstacles to entrepreneurship and innovation from a gender perspective. The survey results indicate that women entrepreneurs are faced with the same challenges as male entrepreneurs, but women entrepreneurs face some additional challenges such as lack of visibility and access to support networks, and cultural acceptance. The difficulties that women face have helped them embrace the opportunities provided by information and communications technologies (ICT) in creating marketing channels, collecting customer information and improving efficiencies in their business processes. As ICTs play an important role in creating competitive advantage, the survey argues that policymakers in both developing and developed economies need to start a dialogue about how to support increased innovation in women's enterprises.

In Serbia, along with the growing awareness of the need of policies in support of innovative enterprises, the issue of policies and support measures targeting innovative women entrepreneurs is gaining importance. There is a lack of comprehensive research on innovative activities in general, and on innovative women entrepreneurial activities as well. However, available research results clearly indicate that women entrepreneurship is insufficiently supported. Based on a qualitative study on women entrepreneurship in Serbia, Zlatkov-Cvetković (2015) found that comprehensive measures are needed in order to increase women entrepreneurship, that a joint action of policy makers, representatives of banks, experts, and NGO's is necessary in order to encourage and support female entrepreneurship in Serbia. More precisely, specific measures are needed such as credit lines, guarantee funds and business incubators for female entrepreneurs, as well as changes in the traditional role of women as a precondition for alarming on women inequality.

Popović-Pantić (2014) conducted a study on female entrepreneurship and innovation in Serbia in the context of EU competitiveness. The findings show that women 
prefer incremental to radical innovation of products/services, as well as that they are highly aware of the importance of innovation for enterprise's development. Also, the results point out to the small share of women using programs to support the innovativeness and competitiveness of SMEs is, that their capacities to perform innovation activities are limited by their financial and human resources. This study clearly indicates that there is a lack of female enterprises with innovative potential, thus pointing out to the need to focus on designing policy measures to promote female innovative entrepreneurship.

\section{Data and Methodology}

The main objective of the research is to empirically analyse and assess the innovative women's entrepreneurship in Serbia. In order to realize the research objective, a field survey was conducted. A field survey was used as a qualitative method of data collection. In conducting a survey, a questionnaire was used and specially designed to provide data on the following five aspects of innovative women's entrepreneurship in Serbia:

1) motivation of women to be entrepreneurs,

2) conditions and opportunities for conducting innovative activity,

3) investments in innovative activity,

4) level of cooperation with relevant institutions in the innovation ecosystem,

5) familiarity with the role and measures of institutions supporting innovative activities.

A field survey was conducted in the period April-June 2018. The sample included 30 women entrepreneurs in 6 research areas. Considering an even geographical and demographical coverage, the research areas covered four statistical regions, i.e. the following six cities: the City of Novi Sad and the City of Subotica in Vojvodina region, the City of Belgrade in Belgrade region, the City of Čacak and the City of Kragujevac in Šmadija and Western Serbia, and the City of Niš in Southern and Eastern Serbia.

The questionnaire was semi structured and consisted of three sections. The first section referred to general information on women entrepreneurs such as name, address, size, core business activity, number of employees. The second section contained questions aimed at providing an insight on motivation of women to be entrepreneurs and the perception of women entrepreneurs on the existing terms and opportunities for conducting innovative activities in Serbia. Also, this section included a question regarding the amount and structure of investments in innovative activities. The third section referred to questions regarding cooperation with higher education institutions and/or scientific research institutions, as well as regarding the extent to which women entrepreneurs are familiar with institutions and measures supporting innovations in Serbia.

The questionnaires were distributed by E-mail to 30 women entrepreneurs in six cities in Serbia. Women entrepreneurs were selected by the random sampling method. The E-mail addresses of women entrepreneurs were provided to the researchers indirectly by the representatives of innovation infrastructure and by innovation promoting actors.

The research methodology implied the use of both primary and secondary data. The secondary data was used to define the theoretical framework of the research, 
methodology, and size of the sample. The primary data is the survey data obtained from the conducted field research.

The data collected was analysed using descriptive statistics. The primary data was analysed using qualitative and quantitative analysis. Afterwards the objectification of results occurred. The innovative potential of women entrepreneurs in Serbia was assessed by using comparative analysis of both primary and secondary data.

\section{Results and discussion}

Empirical analysis of innovative women entrepreneurship indicates that conditions and opportunities for conducting innovative activities in Serbia are poor as they were assessed by $80 \%$ of respondents. Only $20 \%$ of surveyed women entrepreneurs assessed them as solid. None of the surveyed respondents perceive these terms and opportunities as being incentive which points out that government needs to be more actively engaged in improving innovative ecosystem and promoting the level of women's participation in innovative entrepreneurship.

The main reasons for such a poor assessment of existing conditions and opportunities for conducting innovative activities in Serbia, as perceived by women entrepreneurs, refer to the lack of financial resources, insufficient institutional support, lack of relevant procedures and regulations, and macroeconomic environment. Also, $40 \%$ of surveyed women entrepreneurs stated that they are completely unfamiliar with institutions and measures supporting innovations and innovative activities in Serbia.

Regarding motivation of women to become entrepreneurs, $40 \%$ of survey respondents claimed that they started their business to fulfil a dream. Flexibility of working hours was a motivation for $20 \%$ of respondents, while $20 \%$ reported that they were motivated by financial independence. Also, $20 \%$ of surveyed women said that they wanted to take the opportunity in profitable business sectors. The dominant share of respondents who started business to make a dream come true indicates that new market needs and opportunities are still insufficiently recognized by women entrepreneurs in Serbia.

Figure 1: Motivation of women to be entrepreneurs

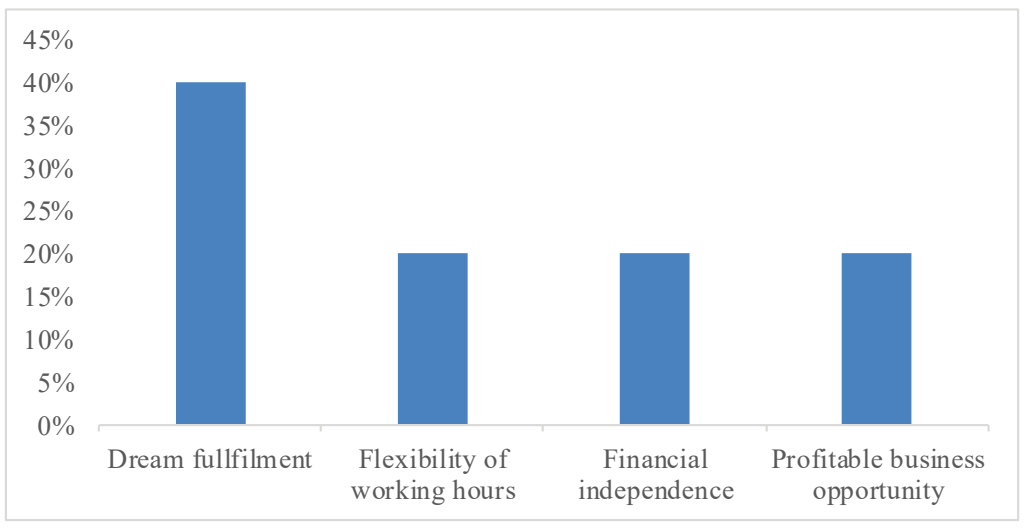

Source: based on data obtained from authors' independent survey 
The structure of investments in innovative activities shows that $50 \%$ of survey respondents invest in research and development activities. More precisely, 33.33\% of surveyed women entrepreneurs invest up to $10 \%$ of sales revenue and $16.7 \%$ invest between $31-40 \%$ of sales revenues in research and development. Also, $16.7 \%$ of respondents invest up to $10 \%$ of sales revenues in outsourcing research and development activities from other enterprises, institutions and organizations. The same percentage of surveyed women entrepreneurs invest between $21-30 \%$ of sales revenue in purchase of machinery, equipment, software, etc.

The results also show that as per $16.7 \%$ of survey respondents invest up $10 \%$ of sales revenues, between $11-20 \%$ of sales revenues and between $21-30 \%$ of sale revenues in design and marketing development.

Table 1: Structure and amount of investment in innovative activity

\begin{tabular}{|l|c|c|c|c|c|c|}
\hline \multirow{2}{*}{ Answer } & \multicolumn{5}{|c|}{$\%$ of sales revenues } \\
\cline { 2 - 7 } & up to 10\% & $11-20 \%$ & $21-30 \%$ & $31-40 \%$ & $41-50 \%$ & no investment \\
\hline R\&D activities & $33.30 \%$ & & & $16.70 \%$ & & $50.00 \%$ \\
\hline $\begin{array}{l}\text { Outsourcing } \\
\text { R\&D from other } \\
\text { enterprises, } \\
\text { institutions or } \\
\text { organizations }\end{array}$ & $16.70 \%$ & & & & & $83.30 \%$ \\
\hline $\begin{array}{l}\text { Purchase of } \\
\text { machinery, } \\
\text { equipment, } \\
\text { software, etc. }\end{array}$ & $16.70 \%$ & $16.70 \%$ & $16.70 \%$ & & & \\
\hline $\begin{array}{l}\text { Design and } \\
\text { marketing } \\
\text { development }\end{array}$ & $16.70 \%$ & & & $83.30 \%$ \\
\hline
\end{tabular}

Source: based on data obtained from authors' independent survey

The survey data leads to the conclusion that women entrepreneurs in Serbia invest rather modest amounts of their sales revenues in innovative activities. Particularly, women on average do make certain investments in research and development and design and marketing development, but very poorly in purchase of machinery, equipment, software, etc. Also, women entrepreneurs rarely rely on outsourcing research and development activities from other enterprises, institutions and organizations which can be perceived as a limiting factor for their innovative business activities and development opportunities.

The research results also indicate that there is a low level of cooperation between women entrepreneurs and higher education institutions and/or scientific research institutions is Serbia. $80 \%$ of respondents stated that they didn't cooperate with any institution but rather developed their innovation by themselves. On one hand, this highlights the need for strengthening relationships and ties between entrepreneurs and science and education. On the other hand, the fact that most surveyed women entrepreneurs developed their innovations by themselves points out that their innovative potential is evident.

Based on the empirical analysis, the innovative potential of women entrepreneurs in Serbia can be assessed as relevant but underdeveloped. The innovative potential 
of women entrepreneurs is immanent, however the place and role of innovation in implementing their business activities is not clearly defined. Since innovation potential is a key precondition of competitiveness, conditions for increased innovative activity of women entrepreneurs need to be created. It is the ability of government to develop the innovation ecosystem in the country, and thus create stimulating environment for creativity and innovation. Governments play a crucial role in promoting innovation through policy measures. The mitigation of the main obstacles pointed out by the surveyed women entrepreneurs as the key factors determining the overall conditions and opportunities for innovative activities in Serbia is to be addressed by the government policy. The lack of financial resources is one of the biggest challenges entrepreneurs face when conducting their business activities, but it particularly becomes relevant in terms of innovations since they usually require significant capital investments in research and development, the purchase of equipment and machinery, prototype development, etc. The risk associated with innovations additionally makes them difficult to finance. Also, the existing macroeconomic environment and the lack of relevant procedures and regulations are perceived by women entrepreneurs as obstacles to innovative activities. The low level of cooperation between women entrepreneurs and institutions has a limiting impact on women's innovative potential since interactions among enterprises, universities and public research institutes are an important type of knowledge and information flow within national innovation ecosystems (OECD, 1997). In addition to that, a significant share of surveyed respondents is completely unfamiliar with institutions and measures supporting innovations and innovative activities in Serbia which brings under discussion the need to improve interactions between different actors in the national innovation ecosystem, and to enable the effects of their engagement to reach as many women entrepreneurs as possible.

The conducted analysis provides valuable insights for raising awareness about importance of innovative women entrepreneurship and getting the issue on the public agenda. Based on the survey results, this paper suggests a set of recommendations for policy makers in Serbia. First, there is a need for a comprehensive research on innovative performances, needs and problems of enterprises, institutions and other participants in national innovation ecosystem. The research results should serve as an evidence for public policy making. Second, innovation policy needs to be more focused on policy measures to promote women innovative activities. Policy measures should include government programmes, mechanisms and financing policy instruments such as government loans to support private research and development and mitigate the limited access of women entrepreneurs to financing. Also, interactions and cooperation between different actors involved in national innovation ecosystem are needed through a systematic approach based on encouraging various forms of linkages between enterprises, universities and research institutions such as joint research, personnel exchanges, cross patenting, purchase of equipment and a variety of other channels (OECD, 1997). Proposed recommendations for policy makers can be summarized as follows:

- Conducting survey research of the needs, problems and performance of all actors in the national innovation system;

- Introducing evidence-based innovation policy approach i.e. application of survey results in policy making;

- Designing policy measures i.e. programmes, mechanisms and financing 
instruments targeting the needs of women innovative entrepreneurs;

- Systematic approach to promoting interactions and cooperation between different actors in the national innovation system through more effective national innovation policy.

\section{Conclusion}

The survey on innovative women's entrepreneurship in Serbia includes assessment of their innovative potential. The assessment is based on the analysis of five different aspects of their innovative activity including motivation to become an entrepreneur, perception on conditions and opportunities for conducting innovative activity, level of cooperation with relevant institutions in national innovation ecosystem, and familiarity with the role and measures of institutions supporting innovative activities in Serbia.

The results obtained from the field survey indicate that women are mostly motivated by a desire to make their dream come true. Besides that, as per $20 \%$ of women are motivated by financial independence, flexibility of working hours and taking advantage of profitable business opportunities. The conditions and opportunities for conducting innovative activities are perceived by $80 \%$ of surveyed respondents as rather poor. The main reasons for such a perception refer to the lack of financial resources, insufficient institutional support, lack of relevant procedures and regulations, and macroeconomic environment. Additionally, $40 \%$ of surveyed women entrepreneurs stated that they are completely unfamiliar with institutions and measures supporting innovations and innovative activities in Serbia. Regarding the structure and amount of investments in innovative activities, women on average modestly invest in research and development and in design and marketing development, but very poorly in purchase of machinery, equipment, software, etc., as well as in outsourcing research and development activities from other enterprises, institutions and organizations. The level of cooperation between women entrepreneurs and institutions involved in national innovation ecosystem is perceived as low and most surveyed women entrepreneurs developed their innovations by themselves which points out to their immanent innovative potential.

Based on the survey results, the innovative potential of women entrepreneurs in Serbia can be assessed as relevant but underdeveloped. In order to develop their innovative potential, improve innovative performances and increase the level of participation in innovative activities, a set of recommendations for policy makers is suggested in the paper.

\section{References}

Avolio, B., Radović-Marković, M. (2013). Women and Entrepreneurship: Female Durability, Persistence and Intuition at Work. London: Ashgate Ltd.

Baughn, C.C., Chua, B.L., \& Neupert, E.K. (2006). The Normative Context for Women's Participation in Entrepreneurship: A Multicountry Study. Entrepreneurship Theory and Practice, 30(5): 687-708. 
Bliss, T.R., \& Garratt, N.L. (2001). Supporting Women Entrepreneurs in Transitioning Economies. Journal of Small Business Management, 39(4): 336-344.

Brindley, C. (2005). Barriers to Women Achieving their Entrepreneurial Potential. International Journal of Entrepreneurial Behavior \& Research, 11(2): 144-161.

Brush, C. (2009). Women Entrepreneurs: A Research Overview. The Oxford Handbooks of Entrepreneurship in Oxford Handbooks in Business and Management C.

De Bruin, A., Brush, C., \& Welter, F. (2006). Introduction to the Special Issue: Towards Building Cumulative Knowledge on Women's Entrepreneurship. Entrepreneurship Theory and Practice, 30(5): 585-593.

Drucker, F.P. (2002). The Discipline on Innovation. Harvard Business Review, 80(8):95$100,102,148$.

Đuričin, S., \& Beraha, I. (2018). Promoting the Intensity of Innovative Activities of SMEs in the Republic of Serbia. Western Balkans Economies in EU Integration, CEMAFI International Association, Nica, France, 188-201.

Erić Nielsen, J., Stojanović-Aleksić, V., \& Zlatanović, D. (2019). The Challenges of Managing the Entrepreneurial Organization. Ekonomika. 65(2): 87-98.

Estrin, S., \& Mickiewicz, T. (2011). Institutions and Female Entrepreneurship. Small Business Economics, 37(4): 397-415.

Hisrich, D.R. (1990). Entrepreneurship/Intrapreneurship. American Psychologist, 45: 209- 222.

Jovanović, O., \& Lazić, M. (2018). Women Entrepreneurship in Serbia - Potentials and Constraints. Journal of Women's Entrepreneurship and Education, 3-4: 60-72.

Knight, F.H. (1942). Profit and Entrepreneurial Functions. The Journal of Economic History. Vol. 2 Supplement: The Tasks of Economic History: 126-132.

Minitti, M., Arenius, P., \& Langowitz, N. (2005). Global Entrepreneurship Monitor: 2004 Report on Women and Entrepreneurship. Babson Park, MA and London: Babson College and London Business School.

Nissan, E., Carrasco, I., \& Castaño, M.S. (2012). Women Entrepreneurship, Innovation, and Internationalization. Women's Entrepreneurship and Economics, Springer, New York, 125-142.

OECD. (1997). National Innovation Systems, available at: https://www.oecd.org/ science/inno/2101733.pdf

Orhan, M., \& Scott, D. (2001). Why Women Enter into Entrepreneurship: An Explanatory Model. Women in Management Review, 16(5): 232-247.

Popović-Pantić, S. (2014). An Analysis of Female Entrepreneurship and Innovation in Serbia in the Context of EU Competitiveness. Economic Annals. 59(200): 61-90.

Radović-Marković, M. (2018). Female Entrepreneurship Opportunity: Home-Based Genealogy Business. Journal of Women's Entrepreneurship and Education, 3-4: 20-33.

Radović-Marković, M., Brnjas, Z., \& Simović, V. (2019). The Impact of Globalization on Entrepreneurship. Economic Analysis: Applied Research in Emerging Markets, 52(1): 56-68. 
Schumpeter, J. (1934). The Theory of Economic Development. Cambridge, MA: Harvard University Press.

Stošić, I., Bodroža, D., \& Đukić, M. (2019). Analysis of Cooperation between Science and Business in the Function of Improving the Effectiveness of the Republic of Serbia Economic Growth. Economic Analysis: Applied Research in Emerging Markets, 52(1): 138-148.

UNCTAD. (2013). A Survey on Women's Entrepreneurship and Innovation, available at: https://empretec.unctad.org/wp-content/uploads/2015/01/UNCTAD_DIAE_ ED_2013_1.pdf

Verheul, I., \& Thurik, R. (2001). Start-up Capital: Does Gender Matter?. Small Bus Economics, 16(4): 329-345.

Verheul, I., \& van Stel, A. (2007). Entrepreneurial Diversity and Economic Growth. Research Paper ERS-2007-070-ORG. Erasmus Research Institute of Management (ERIM).

Verheul, I., van Stel, A., \& Thurik, R. (2006). Explaining Female and Male Entrepreneurship at the Country Level. Entrepreneurship and Regional Development, 18: 151-183.

Warnecke, T. (2013). Entrepreneurship and Gender: An Institutional Perspective. Journal of Economic Issues, 47(2): 455-464.

Welter, F. (2004). The Environment for Female Entrepreneurship in Germany. Journal of Small Business and Enterprise Development, 11(2); 212-221.

Zapalska, A. (1997). The Profile and Motivation of Women Entrepreneurs in Mauritius. Journal of Small Business Management, 35(4): 76-82.

Zlatkov-Cvetković, Marina. (2015). Women entrepreneurship in Serbia: A qualitative study of the perceived enabling factors for the female entrepreneurship. Master Thesis, Swedish University of Agricultural Sciences. 